\title{
Communication
}

\section{Foundation Pit Collapse on 8 June 2019 in Nanning, China: A Brief Report}

\author{
Yie-Tong Chin ${ }^{1}$, Shui-Long Shen ${ }^{2,3, *} \mathbb{}$, An-Nan Zhou ${ }^{4}$ and Jun Chen ${ }^{1}$ \\ 1 Department of Civil Engineering, School of Naval Architecture, Ocean, and Civil Engineering, \\ Shanghai Jiao Tong University, Shanghai 200240, China; ytchin@sjtu.edu.cn (Y.-T.C.); \\ chen_jun@sjtu.edu.cn (J.C.) \\ 2 Department of Civil and Environmental Engineering, College of Engineering, Shantou University, \\ Shantou 515063, China \\ 3 Key Laboratory of Intelligent Manufacturing Technology (Shantou University), Ministry of Education, \\ Shantou 515063, China \\ 4 Civil and Infrastructure Engineering, School of Engineering, Royal Melbourne Institute of \\ Technology (RMIT), Melbourne, VIC 3001, Australia; annan.zhou@rmit.edu.au \\ * Correspondence: shensl@stu.edu.cn; Tel.: +86-54-8650-4551
}

Received: 29 June 2019; Accepted: 8 October 2019; Published: 12 October 2019

check for updates

\begin{abstract}
This short communication reports on the recent incident of a foundation pit collapse at a construction site on 8 June 2019 in Nanning City of Guangxi Province, China. There were no injuries or casualties reported for this incident. This report presents the incident background, management measures taken after the incident, and a brief discussion of the causes of the incident. Some mitigation measures are suggested to prevent similar incidents in the future based on the preliminary analysis.
\end{abstract}

Keywords: foundation collapse; report; Nanning

\section{Introduction}

The economic boom in China has triggered rapid urbanization over the past 20 years, leading to a continuous increase in demand for residential, commercial, and office areas, and urban infrastructure such as highways, bridges, and metro systems [1-10]. To meet the market demand, developers and contractors prioritize short completion times for these projects. In addition, economic considerations also play an important part in construction projects. These factors easily create room for errors to occur, which may compromise safety onsite. The Ministry of Emergency Management (MEM) announced that there were 1732 accidents and 1752 deaths in the construction industry for the first half of 2018, which the MEM blamed on the chaotic subcontracting system and the failure of contractors to abide by safety laws and regulations [11]. According to Ismail et al. [12], there are several risk factors which affect the general safety onsite, including the organizational structure, communication, clear instructions, safety culture, codes and standards, training, leadership, and responsibility. Previous research has shown that many construction incidents are due to lack of strategic management and effective control of risk [13-16]. In recent years, there have been many reported cases of foundation collapse in China. Table 1 shows some recent cases of foundation collapse in China, and the reasons behind the collapse [17-20]. Most of these incidents could have been prevented, but similar cases continue to happen. 
Table 1. Incidents of recent foundation pit collapse.

\begin{tabular}{|c|c|c|c|c|}
\hline Incident Date & Incident Location & Type of Incident & Reasons for Incidents & Casualties \\
\hline 15 November 2008 & $\begin{array}{l}\text { Hangzhou City, } \\
\text { Zhejiang Province }\end{array}$ & $\begin{array}{l}\text { Metro Foundation } \\
\text { Collapse }\end{array}$ & $\begin{array}{l}\text { Insufficient foundation wall design } \\
\text { Heavy rain affecting the soil } \\
\text { conditions } \\
\text { Inefficient monitoring onsite }\end{array}$ & $\begin{array}{l}21 \text { deaths } \\
24 \text { injuries }\end{array}$ \\
\hline 19 March 2009 & $\begin{array}{c}\text { Xining City, } \\
\text { Qinghai Province }\end{array}$ & $\begin{array}{l}\text { Foundation } \\
\text { Collapse }\end{array}$ & $\begin{array}{l}\text { Constructed foundation was found to } \\
\text { be different from design plans } \\
\text { Incompetent monitoring from } \\
\text { relevant authorities }\end{array}$ & $\begin{array}{l}20 \text { trapped } \\
8 \text { deaths }\end{array}$ \\
\hline 10 November 2014 & $\begin{array}{l}\text { Foshan City, } \\
\text { Guangdong } \\
\text { Province }\end{array}$ & $\begin{array}{l}\text { Foundation Pit } \\
\text { Collapse }\end{array}$ & $\begin{array}{l}\text { Inadequate foundation wall design } \\
\text { Inefficient safety management on site } \\
\text { Workers lack health and safety } \\
\text { knowledge }\end{array}$ & 3 deaths \\
\hline \multirow[t]{2}{*}{7 February 2018} & \multirow{2}{*}{$\begin{array}{l}\text { Foshan City, } \\
\text { Guangdong } \\
\text { Province }\end{array}$} & \multirow[t]{2}{*}{ Ground Collapse } & $\begin{array}{l}\text { Shield tunnel failed due to leakage in } \\
\text { shield tail seal system }\end{array}$ & $\begin{array}{l}11 \text { deaths } \\
1 \text { missing }\end{array}$ \\
\hline & & & Poor safety management onsite & 8 injuries \\
\hline 10 April 2019 & $\begin{array}{l}\text { Yangzhou City, } \\
\text { Jiangsu Province }\end{array}$ & $\begin{array}{l}\text { Foundation Pit } \\
\text { Collapse }\end{array}$ & $\begin{array}{c}\text { Unawareness of geological conditions } \\
\text { of the site } \\
\text { Excavation of foundation pit on } \\
\text { unauthorized site }\end{array}$ & $\begin{array}{l}5 \text { deaths } \\
1 \text { injury }\end{array}$ \\
\hline 8 June 2019 & $\begin{array}{l}\text { Nanning City, } \\
\text { Guangxi Province }\end{array}$ & $\begin{array}{l}\text { Foundation Pit } \\
\text { Collapse }\end{array}$ & $\begin{array}{l}\text { Inadequate retaining wall design } \\
\text { Bursting waterpipe causes } \\
\text { deformation of retaining wall } \\
\text { Inefficient monitoring system }\end{array}$ & $\begin{array}{l}\text { No casualties } \\
\text { reported }\end{array}$ \\
\hline
\end{tabular}

This short communication presents a recent incident of a foundation pit collapse at a construction site on 8 June 2019 in Nanning City of Guangxi Province, China. There were no injuries or casualties reported from this incident. The incident background, management measures taken after the incident, and a brief discussion of the causes which resulted in the incident are presented. Some mitigation measures are suggested to prevent similar incidents in the future based on the preliminary analysis.

\section{Background}

On 8 June 2019, a foundation pit collapsed at a construction site in Nanning, a city in Guangxi Province of China. The incident happened around 5:30 p.m. local time at the construction site of a new office building under the Phase 2 development of Nanning Greenland Central Square, located adjacent to Dongge Road (location shown in Figure 1). The failure of the foundation caused the collapse of a section of Dongge Road. The collapsed area was about $60 \mathrm{~m}$ long, and $15 \mathrm{~m}$ wide, with a volume of approximately 4500 cubic meters. There were no reported injuries or casualties from this accident.

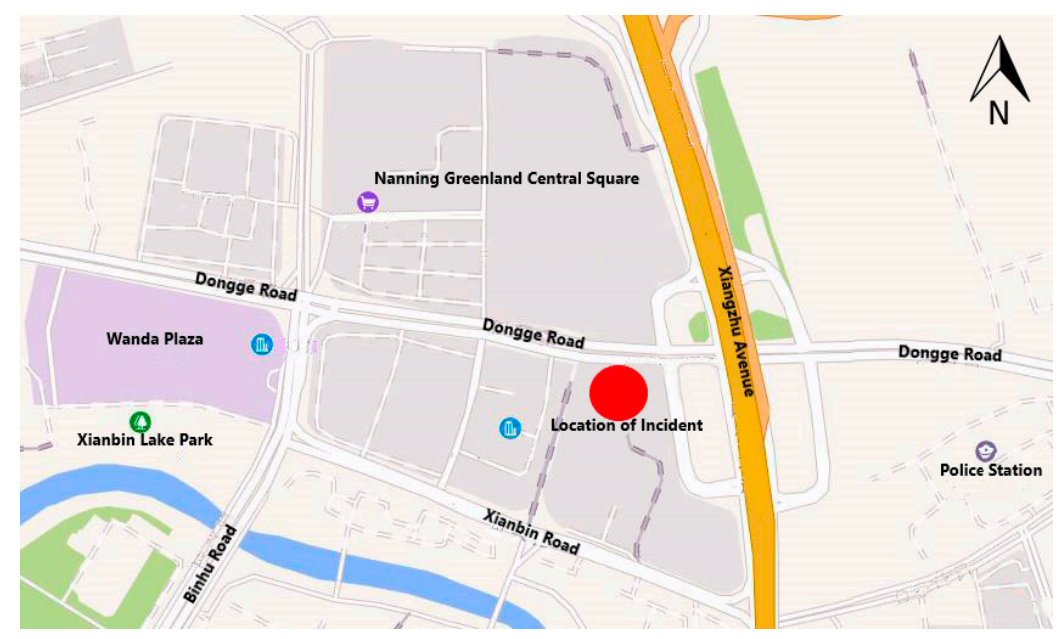

Figure 1. Site location of the incident, marked in red (adapted from Gaode Maps). 


\section{Collapse Incident-Before and After}

\subsection{Before the Incident}

One day before the incident (7 June 2019), construction workers reported cracks on the road pavement around the foundation pit. The cracks, which were $40 \mathrm{~cm}$ in width and covered a distance of $20 \mathrm{~m}$, were formed due to subsidence of the ground layer (Figure 2). After receiving the report, construction work on the entire site was ceased while relevant experts carried out site investigation and monitored the cracks for any further deformation. The construction work continued after the experts considered that the situation was still safe.

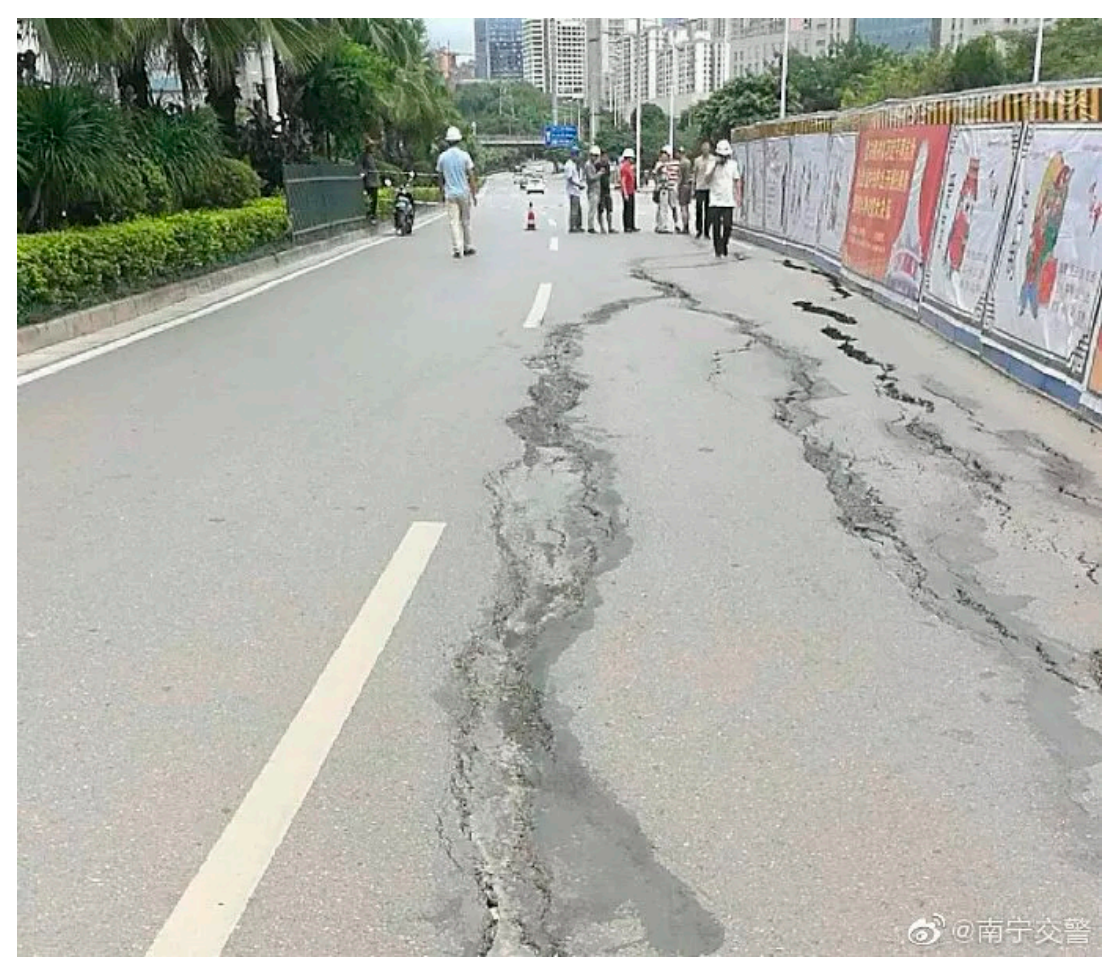

Figure 2. Cracks on the surface of Dongge Road prior to the incident (source: https://mp.weixin.qq. com/s/nMGCnVwHjjlVq_np9ITXwg).

However, at 11:30 am (8 June 2019), the monitoring data showed a tangible change. The relevant authorities, including the Construction Management Centre of Housing Construction Bureau, Nanning City, were notified about the potential for incident. The authorities performed mitigation measures to ensure personnel safety. They closed off a part of Dongge Road near the site to prevent public access, and the site and people within its vicinity were evacuated. Control measures were also taken onsite to minimize the effect of the collapse. About an hour prior to the incident, the cracked road surface began to sink, forming a large pit, and cracks formed in the foundation walls (Figure 3). At around 5: $30 \mathrm{pm}$ local time, the retaining wall collapsed (Figures 4 and 5). 


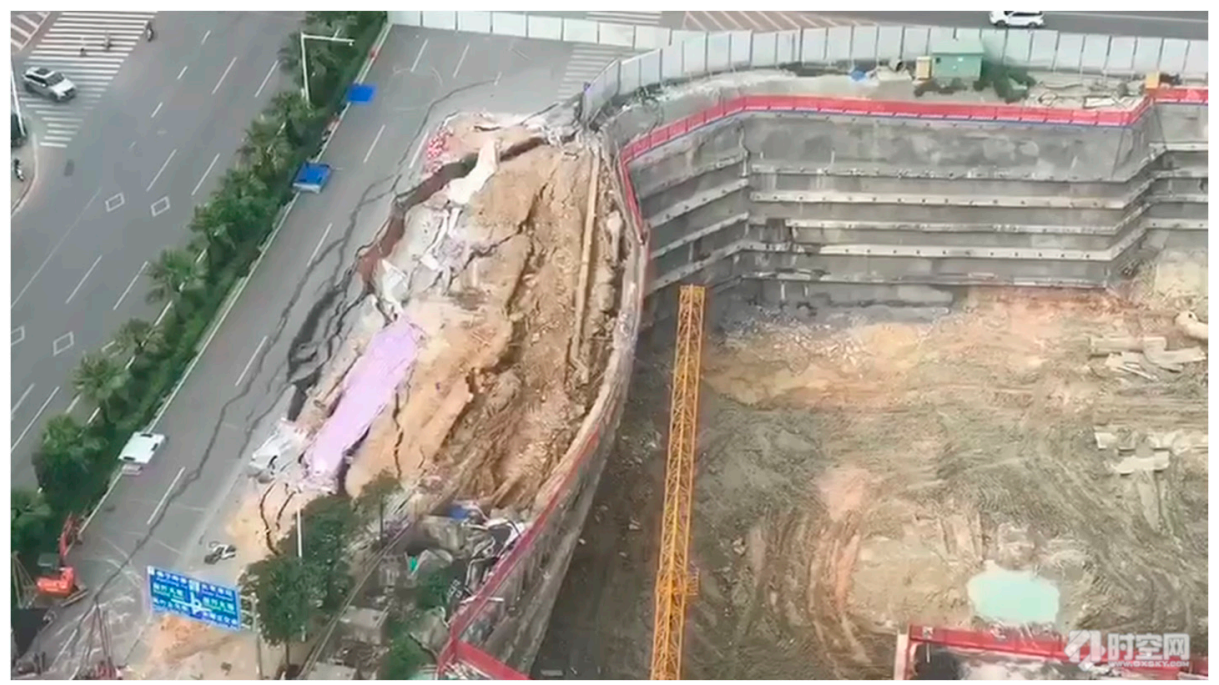

Figure 3. Road surface prior to the collapse (source: http://bbs.gxsky.com/forum-viewthread.php? mod=viewthread\&tid $=17158735 \&$ page $=1$ ).

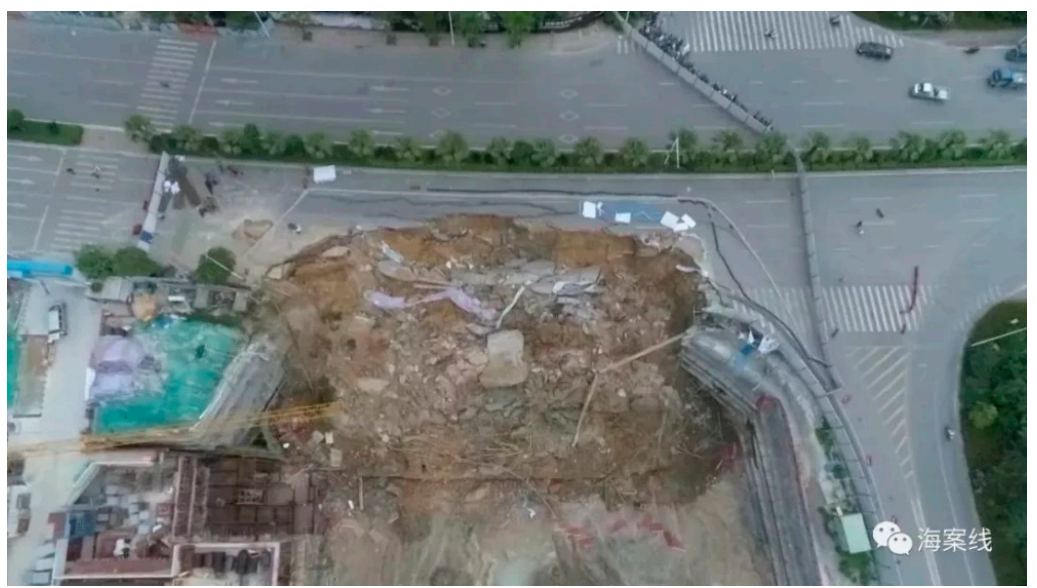

Figure 4. Collapsed foundation (plan view) (source: https://mp.weixin.qq.com/s/U9TbiDpfH VxxUqvq3Gw0iw).

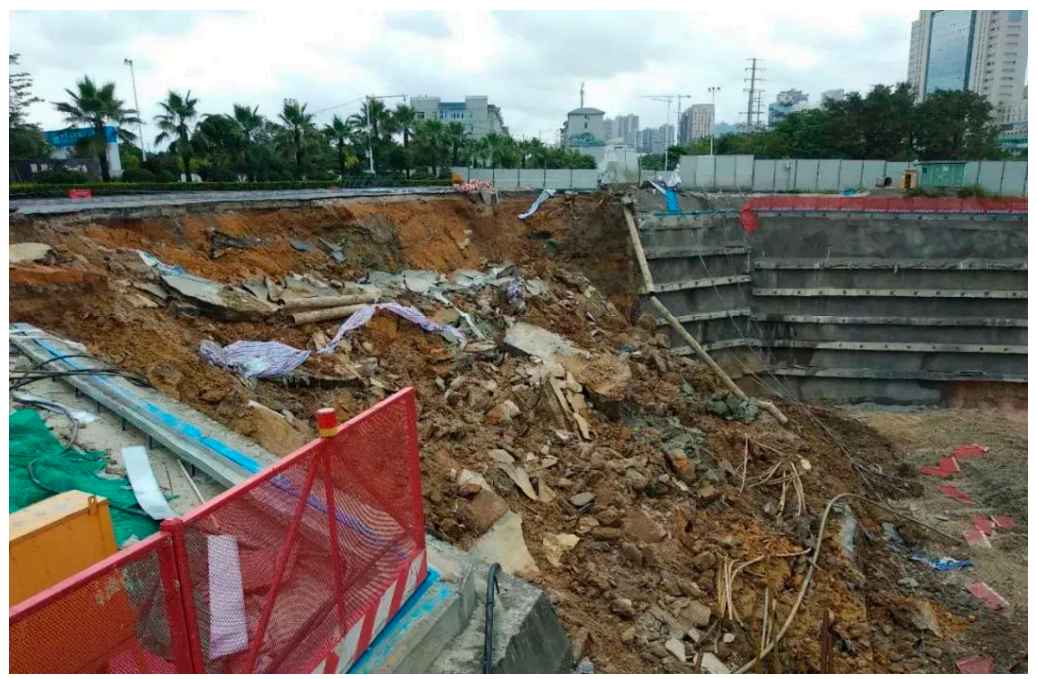

Figure 5. Collapsed foundation (side view) (source: https://mp.weixin.qq.com/s/nMGCnVwHjjlVq_ np9ITXwg). 


\subsection{Incident Aftermath}

To avoid any post-disaster incidents, the Construction Management Centre of Housing Construction Bureau, Nanning City, commissioned third-party monitoring agencies to monitor the roads and buildings around the collapsed road. Backfilling was executed immediately to prevent any further collapse or erosion of the soil. As this incident happened during the rainy season, rainwater had to be diverted from the road surface and prevented from infiltrating the site. With the help of the local waterworks department, the water flow from the municipal rainwater pipes was intercepted. Additionally, additional anchor supports for the retaining walls were designed and are to be implemented onsite as soon as possible.

An onsite investigation was conducted by the Construction Management Centre of Housing Construction Bureau, Nanning City. Relevant authorities confirmed that the main reason for this collapse was the deformation of the retaining wall, which led to a loss of soil. Municipal water pipes of $500 \mathrm{~mm}$ diameter that were sitting on the soil was found to suffer from long-term leakage, which caused the soil around them to soften and settle around the foundation pit. The cumulative loss of soil underneath the water pipes led to a burst of the unsupported water pipes. As a result of the bursting water pipes, the anchor cable structure failed and the foundation pit support further deformed, eventually leading to the collapse of the pit.

\section{Discussion}

Although the collapse has been mainly attributed to the deformation in the retaining wall due to movement of soil, there are some other important factors that could have affected the occurrence of this incident. For example, one key point was the insufficient length of the anchor supporting the retaining wall. Officials released a copy of a technical drawing showing a cross-section of the retaining wall. A reproduced version of the drawing is shown in Figure 6. As shown in Figure 6, the retaining wall was supported by a combination system of pile foundations and horizontal ground anchors. The $150 \mathrm{~mm}$ diameter anchors had a lateral spacing of $5 \mathrm{~m}$ and a lock-off load of zero. Further design details of the anchors are shown in Figure 6. The potential failure surfaces due to active failure and shear failure are also shown in the figure, where the curved lines correspond to the upper and lower bounds of failure by shearing and the straight line corresponds to failure by pullout. The upper and lower bounds were established based on the slip surfaces with the highest factor of safety (F.O.S) and lowest F.O.S respectively, where the F.O.S is influenced by factors like active earth pressure and soil properties [21]. As shown in Figure 6, the anchor head of the top layer was near the failure surface due to pullout, which indicates that the anchor length was insufficient [21-23]. Thus, the deformation at the top of retaining wall was large. The leakage from the pipe caused an increase in pore water pressure acting on the back of the wall, which reduced the safety factor of the retaining wall. After being pulled out, the anchor collapsed with the soil mass due to the forces induced by the movement of the soil mass. Jet mixing the anchor piles is another option that would have helped to control the deformation and ensure the stability of the retaining wall [24-26]. The distance between each pile could have been reduced to allow for more stability. Moreover, the interior bracing system should have been designed to prevent large deformation during excavation [14,27]. 


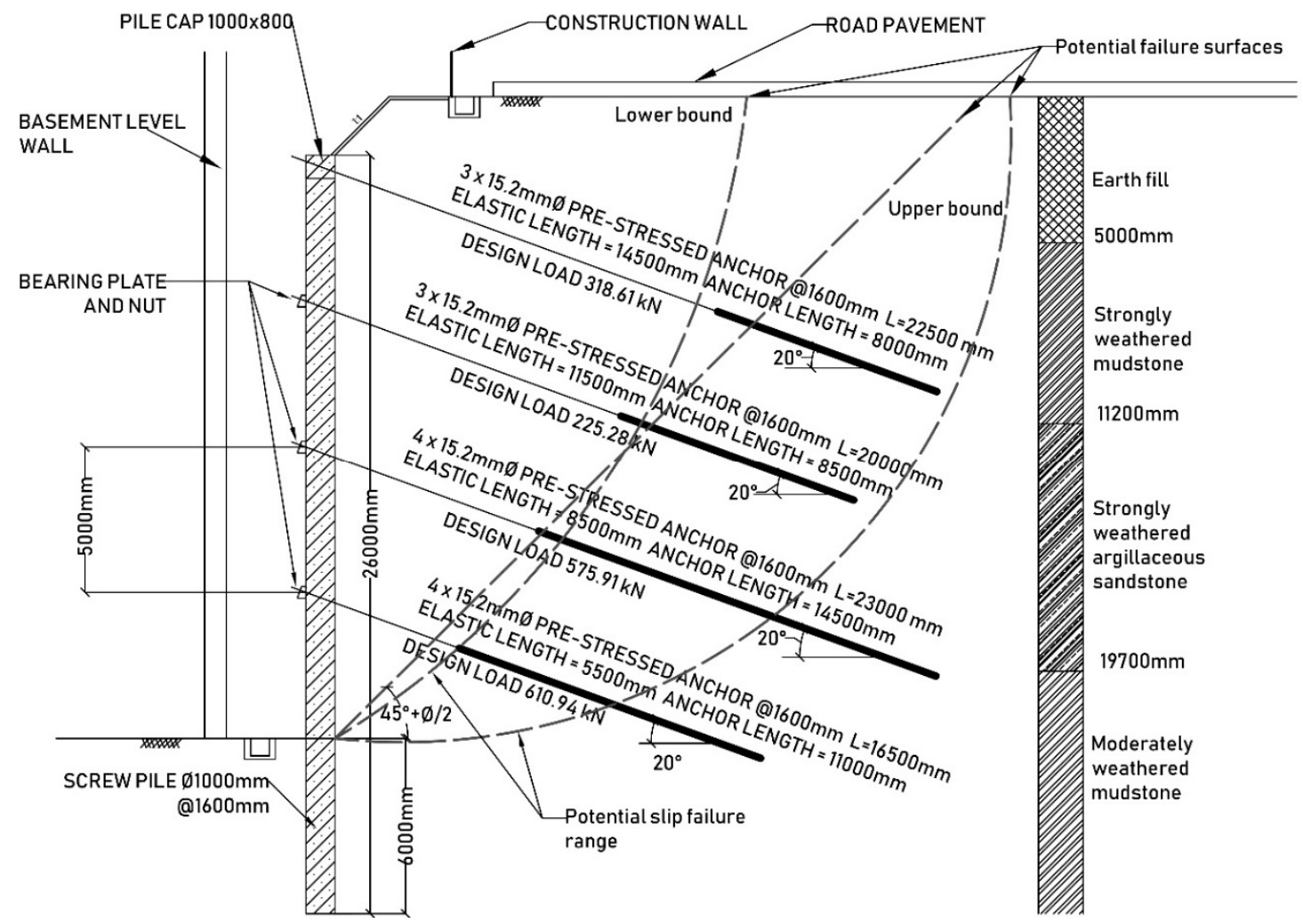

Figure 6. Cross-section of retaining wall with anchoring details.

There was no information on the location of the water pipe, and it has been speculated that the design team had no knowledge of the existence of the pipes, as it was not indicated in the technical drawings, and no design allowances were considered. However, since the site was located adjacent to a public road, the design team should have investigated the possibility of public services and utility pipes underneath the road, and provided necessary allowances in their design.

The soil profile of the slope behind the retaining wall was made up of $5 \mathrm{~m}$ of earth fill, followed by $6.2 \mathrm{~m}$ of strongly weathered mudstone, $8.5 \mathrm{~m}$ of strongly weathered argillaceous siltstone, and moderately weathered mudstone, as shown in Figure 6 . The layers of clayey soil had high water retention properties, which swelled when exposed to the leaking pipe water. This phenomenon resulted in the deformation of the retaining wall and could also provide a possible explanation as to why the leaking water pipes went unnoticed. Thus, a dewatering system should have been installed to pump out the groundwater and the leaked water from the pipe system, as dewatering is a useful technique for prevention of large deformation and failure $[9,24,26,28-30]$. Therefore, from a technical aspect, a supporting system (retaining pile, anchor, bracing support), dewatering system, and soil properties should be considered in an optimized way [15,31,32].

Another key point is the inefficiency in supervision and decision-making. Strict guidelines should be implemented for relevant personnel involved in monitoring works. In this case, the cracks that appeared on the road surface generally took time to form; however, construction workers only reported the cracks on the road surface a day before the incident. Abnormal changes observed onsite is a warning sign worth inspecting. If such discrepancies occur, they should be reported immediately to the site managers, who should then attempt to resolve the matter. Monitoring and supervision during the construction phase is an essential part of avoiding inconsistencies between the design and the actual construction work carried out onsite. Instead of depending solely on human communication, the monitoring system could be improved by utilizing robotics such as sensors able to automatically send out real-time information. 


\section{Conclusions}

This report presents the collapse of a foundation pit retaining wall in Nanning City on 8 June 2019. The collapse happened because of anchor-pile retaining system failure, which led to the deformation of the retaining wall. Additionally, the bursting of water pipes in the retained soil led to a decrease of the strength and stiffness of the soil and to further deformation of the wall. Some suggestions have been proposed to prevent similar accidents in the future. Risk assessment should be conducted initially. Monitoring and supervision of works should be prioritized to ensure that every incident or anomaly is reported so that the appropriate action can be taken by the person in charge. An effective monitoring system involving the use of robotics or by engaging third-party health and safety inspectors could increase monitoring efficiency. Regular onsite checks by relevant authorities should be carried out regularly to enhance the performance of appropriate health and safety measures. When designing for a project, the engineer should consider the surrounding environment. Routine checks should also be carried out to make sure that construction works match the approved design, and heavier penalties should be given out to those who do not comply with the building codes.

Author Contributions: This manuscript represents a result of collaborative teamwork. Conceptualization, S.-L.S. and A.-N.Z.; Methodology, Y.-T.C.; Supervision, S.-L.S. and A.-N.Z. Revision, J.C. All authors have read and approved the final manuscript.

Funding: The research work described herein was funded by the Research Funding of Shantou University for New Faculty (Grant No. NTF19024-2019), the National Basic Research Program of China (973 Program: 2015CB057806) and the Innovative Research Funding of the Science and Technology Commission of Shanghai Municipality (Grant No. 18DZ1201102).

Acknowledgments: The research work described herein was funded by the National Basic Research Program of China. This financial support is gratefully acknowledged.

Conflicts of Interest: The authors declare no conflict of interest.

\section{References}

1. Lyu, H.-M.; Cheng, W.-C.; Shen, J.S.; Arulrajah, A. Investigation of Collapsed Building Incidents on Soft Marine Deposit: Both from Social and Technical Perspectives. Land 2018, 7, 20. [CrossRef]

2. Lyu, H.-M.; Sun, W.-J.; Shen, S.-L.; Arulrajah, A. Flood risk assessment in metro systems of mega-cities using a GIS-based modeling approach. Sci. Total Environ. 2018, 626, 1012-1025. [CrossRef] [PubMed]

3. Lyu, H.-M.; Shen, S.-L.; Zhou, A.; Yang, J. Perspectives for flood risk assessment and management for mega-city metro system. Tunn. Undergr. Space Technol. 2019, 84, 31-44. [CrossRef]

4. Lyu, H.-M.; Shen, S.-L.; Zhou, A.-N.; Zhou, W.-H. Flood risk assessment of metro systems in a subsiding environment using the interval FAHP-FCA approach. Sustain. Cities Soc. 2019, 50, 101682. [CrossRef]

5. Ren, D.-J.; Shen, S.-L.; Arulrajah, A.; Wu, H.-N. Evaluation of ground loss ratio with moving trajectories induced in double-O-tube (DOT) tunnelling. Can. Geotech. J. 2018, 55, 894-902. [CrossRef]

6. Xu, Y.-S.; Shen, S.-L.; Lai, Y.; Zhou, A.-N. Design of sponge city: Lessons learnt from an ancient drainage system in Ganzhou, China. J. Hydrol. 2018, 563, 900-908. [CrossRef]

7. Wu, H.-N.; Shen, S.-L.; Liao, S.-M.; Yin, Z.-Y. Longitudinal structural modelling of shield tunnels considering shearing dislocation between segmental rings. Tunn. Undergr. Space Technol. 2015, 50, 317-323. [CrossRef]

8. Wu, H.-N.; Shen, S.-L.; Yang, J. Identification of Tunnel Settlement Caused by Land Subsidence in Soft Deposit of Shanghai. J. Perform. Constr. Facil. 2017, 31, 04017092. [CrossRef]

9. Wu, Y.-X.; Lyu, H.-M.; Han, J.; Shen, S.-L. Dewatering-Induced Building Settlement around a Deep Excavation in Soft Deposit in Tianjin, China. J. Geotech. Geoenvironmental Eng. 2019, 145, 05019003. [CrossRef]

10. Zhao, X.-H.; Cheng, W.-C.; Shen, J.S.; Arulrajah, A. Platform collapse incident of a power plant in Jiangxi, China. Nat. Hazards 2017, 55, 482-1265. [CrossRef]

11. China Labour Bulletin. China's Most Dangerous Industry is Getting More Dangerous. 2018. Available online: https://clb.org.hk/content/china|T1\textquoterights-most-dangerous-industry-getting-more-dangerous (accessed on 25 June 2019).

12. Ismail, Z.; Doostdar, S.; Harun, Z. Factors influencing the implementation of a safety management system for construction sites. Saf. Sci. 2012, 50, 418-423. [CrossRef] 
13. Liu, X.-X.; Shen, S.-L.; Xu, Y.-S.; Yin, Z.Y. Analytical approach for time-dependent groundwater inflow into shield tunnel face in confined aquifer. Int. J. Numer. Anal. Methods Geomech. 2018, 42, 655-673. [CrossRef]

14. Wu, H.-N.; Shen, S.-L.; Yang, J.; Zhou, A. Soil-tunnel interaction modelling for shield tunnels considering shearing dislocation in longitudinal joints. Tunn. Undergr. Space Technol. 2018, 78, 168-177. [CrossRef]

15. Elbaz, K.; Shen, S.-L.; Zhou, A.; Yuan, D.-J.; Xu, Y.-S. Optimization of EPB Shield Performance with Adaptive Neuro-Fuzzy Inference System and Genetic Algorithm. Appl. Sci. 2019, 9, 780. [CrossRef]

16. Lyu, H.M.; Sun, W.J.; Shen, S.L.; Zhou, A.N. Risk Assessment Using a New Consulting Process in Fuzzy AHP. J. Constr. Eng. Manag. 2019, in press. [CrossRef]

17. Zhou, X.-H.; Shen, S.-L.; Xu, Y.-S.; Zhou, A.-N. Analysis of Production Safety in the Construction Industry of China in 2018. Sustainability 2019, 11, 4537. [CrossRef]

18. Zhang, K.C.; Li, J.M. Accident analysis for 08.11.15 foundation pit collapse of Xianghu Station of Hangzhou metro. Chin. J. Geotech. Eng. 2010, 32, 338.

19. Zhu, Y.P.; Ye, S.H.; Mo, Y. Analysis and treatment of a deep foundation pit accident in Xining, Qinghai Province. Chin. J. Geotech. Eng. 2010, 32, 404-409.

20. Zhou, H. Analysis of Foundation Pit Collapse using a building construction project in Guangdong as an example. Constr. Saf. 2017, 2, 9-11. [CrossRef]

21. Bergado, D.T. Soft Ground Improvement: In Lowland and Other Environments; ASCE Press: New York, NY, USA, 1996.

22. Ma, L.; Shen, S.L.; Du, Y.J.; Sun, W.J. A Case Study of the Behavior of Soil-Nail Supported Deep Mixed Wall in the Soft Deposit of Shanghai. Lowl. Technol. Int. 2011, 13, 1-8.

23. Han, J. Principles and Practice of Ground Improvement; Wiley: Hoboken, NJ, USA, 2015.

24. Shen, S.-L.; Wu, Y.-X.; Misra, A. Calculation of head difference at two sides of a cut-off barrier during excavation dewatering. Comput. Geotech. 2017, 91, 192-202. [CrossRef]

25. Tan, Y.; Lu, Y. Why Excavation of a Small Air Shaft Caused Excessively Large Displacements: Forensic Investigation. J. Perform. Constr. Facil. 2017, 31, 4016083. [CrossRef]

26. Wang, X.-W.; Yang, T.-L.; Xu, Y.-S.; Shen, S.-L. Evaluation of optimized depth of waterproof curtain to mitigate negative impacts during dewatering. J. Hydrol. 2019, 577, 123969. [CrossRef]

27. Tan, Y.; Wei, B.; Lu, Y.; Yang, B. Is Basal Reinforcement Essential for Long and Narrow Subway Excavation Bottoming Out in Shanghai Soft Clay? J. Geotech. Geoenvironmental Eng. 2019, 145, 05019002. [CrossRef]

28. Xu, Y.-S.; Wu, Y.-X.; Shen, S.-L.; Yin, Z.-Y. Characteristics of groundwater seepage with cut-off wall in gravel aquifer. I: Field observations. Can. Geotech. J. 2015, 52, 1526-1538.

29. Wu, Y.-X.; Shen, S.-L.; Yin, Z.-Y.; Xu, Y.-S. Characteristics of Groundwater Seepage with Cut-off Wall in Gravel Aquifer. II: Numerical Analysis. Can. Geotech. J. 2015, 52, 1539-1549. [CrossRef]

30. Xu, Y.-S.; Yan, X.-X.; Shen, S.-L.; Zhou, A.-N. Experimental investigation on the blocking of groundwater seepage from a waterproof curtain during pumped dewatering in an excavation. Hydrogeol. J. 2019, in press. [CrossRef]

31. Zhang, N.; Shen, S.-L.; Zhou, A.-N.; Xu, Y.-S. Investigation on Performance of Neural Networks Using Quadratic Relative Error Cost Function. IEEE Access 2019, 7, 106642-106652. [CrossRef]

32. Yin, Z.-Y.; Jin, Y.-F.; Shen, S.-L.; Huang, H.-W. An Efficient Optimization Method for Identifying Parameters of Soft Structured Clay by an Enhanced Genetic Algorithm and Elastic-Viscoplastic Model. Acta Geotech. 2017, 12, 849-867. [CrossRef]

(C) 2019 by the authors. Licensee MDPI, Basel, Switzerland. This article is an open access article distributed under the terms and conditions of the Creative Commons Attribution (CC BY) license (http://creativecommons.org/licenses/by/4.0/). 